\title{
電動車いす等の交通事故から想定する 搭乗型移動支援ロボットの危険性
}

\author{
横関 俊也 1 \\ 1正会員 科学警察研究所 交通科学第一研究室（†277-0882 千葉県柏市柏の葉6-3-1） \\ E-mail: yokozeki@nrips.go.jp
}

\begin{abstract}
本研究では，搭乗型移動支援ロボットに近いモビリティとして電動車いすを想定し，電動車いすの交通 事故を分析することにより，搭乗型移動支援ロボットの安全性を検証することとした。 その結果, 電動車 い寸が車道を走行中（横断中を除く）に重傷以上の事故にあいやすいことがわかった．また，歩道がある にもかかわらず，電動車いすが車道を走行して発生している事故については，現地の歩道の幅員が狭い， 段差や障害物がある等のやむをえない事情により車道を走行して事故に至っていると想定できるケースが あった。 そのため, 搭乗型移動支援ロボットを安全な状況で普及させていくには, 段差のない幅広な歩道 網を整備していくとともに, やむを得ず車道を走行するときに備えた車体整備や操作技術の習得等が重要 であると考えられた。
\end{abstract}

Key Words : personal mobility, electric wheelchair, traffic safety, traffic accident, sidewalk

\section{1. はじめに}

各国において，様々な種類や用途の搭乗型移動支援口 ボットの開発・実用化がなされている．セグウェイに代 表される立ち乗り型のもの，座りながら搭乗する車いす 型のもの，一輪車タイプのもの等がある. これらのモビ リティがすでに公道を走行している国もあるが，日本国 内においては法規制による影響等もあり，特区等におい てのみ公道での実証実験が行われていた1).しかし，平 成27年7月には各種規程2),3)が整備されて, 全国の公道で の実証実験が可能となった，今後，各地での実証実験を とおして，搭乗型移動支援ロボットの安全性が検証され ることで，これらの新しいモビリティが普及していくこ とも考えられる.

ここで，現在実施されている公道での実証実験におい ては，通行できる場所は幅員の広い歩道等の安全性の高 い道路のみに限定され，さらに，保安要員を配置する等 の安全対策を行っていることが多く, 交通事故は発生し にくい状況にあると考えられる，そのため，実際に発生 した交通事故から走行方法等の安全性を検証することは 難しい状況にある，そこで，本研究では搭乗型移動支援 ロボットに近いモビリティとして電動車いす等を想定し, 電動車いす等の交通事故を分析することにより，搭乗型 移動支援ロボットの安全性を検証することとした.

\section{2. 既存研究と本研究の位置づけ}

国内における搭乗型移動支援ロボットの交通事故に関 する研究は，実証実験以外での公道での走行が行われて いないこともあり少ないと考えられる. 海外における事 例については，2005-2008の41件のカルテを調査した Boniface et al.による報告4)があり，セグウェイ利用中の事 故は増加傾向にあるうえに重大な症状が多いとされ，危 険性の周知や練習の必要性に言及している，一方，電動 車い寸等の交通事故についてはいくつか分析例がある.

交通事故総合分析センターでは5)平成14年の交通事故統 計データを用いて電動車いすの交通事故について分析し ている.ここでは．電動車いすの交通事故の約 $58 \%$ 交 差点内，約 $28 \%$ が横断歩道上で発生していること, やむ を得ず直線道路の車道を走行していた電動車いすの後ろ から自動車が追突するパターンが多いこと等が指摘され ている.

交通事故以外の搭乗型移動支援ロボットや電動車いす 等の走行時の危険性に着目した研究もある. 田平・上 野のは歩道短部の切り下げの公配と手動及び電動車いす 使用者が感じる負担の関係について分析している. その 結果, 車いす利用者の感じる負担は勾配は障害の程度に より大きく異なり，5\%程度の勾配であっても負担に感 じる使用者がいたとしている，また，切り下げ部におい ても車いす1台分の水平部を確保することで負担が大き 
く軽減できるとしている，井料ら》はパーソナルモビリ ティビークル（以下，PMVとする）の交錯回避行動に ついて，目的地への予測旅行時間が最短になるように回 避行動をする傾向があるとしている，中川ら゙タPMVの 大きさとそれに対する歩行者のパーソナルスペースの関 係について調査した，車両幅やステップ高さを大きくす ると，歩行者のパーソナルスペースも拡大したとしてい る. 溝端・北川99は電動車いすの利用者と販売担当者に 電動車いすの利用状況，歩道上での問題点等についてア ンケートによる調査を行った，その回答からは，歩道を 通行しない理由として，歩道が狭い，歩車道境界の段差， 歩道上の障害物等の理由が上げられていた.

以上の既存研究から，電動車い寸等の利用者は，歩道 が狭い，歩道に段差がある等の事情により車道を走行し て事故が発生している等の実態が想定できる.しかし， 既存研究においては，実際の事故発生地点の状況を踏ま えた考察や，他交通モードでの事故の特徵との比較等は 十分に行われているとはいい難い，本研究では，電動車 いす等が関連する事故について，手動車いすの事故等と 比較を行うとともに，事故の緯度経度情報から発生地点 の道路形状等を詳細にみることで事故に至った要因を詳 細に分析することとした。その結果から導き出された電 動車いす等の事故発生要因や事故対策のうち，搭乗型移 動支援ロボットにおいても共通する点を見出し，搭乗型 移動支援ロボット走行時における危険性を低減させる方 策を考察することとした.

\section{3. 分析方法}

\section{(1) 事故データ等}

本研究では，警察庁で整備する交通事故統計（平成30 年4月 12 日のデータ）を事故データとして用いることと した，交通事故統計には，各事故の発生日時，当事者の 情報, 発生場所, 発生要因等のデータが含まれている.

H24の交通事故統計からは各事故が発生した地点の緯度 経度も記録されるようになり，より詳細な分析が可能と なっている. 当事者の形態としては, 乗用車, 貨物車, 特殊車，二輪車，軽車両，列車，歩行者等の大きな分類 に分けられるが，歩行者の細分類としては，「一般歩行 者」，準歩行者とされる「電動車いす」，「手動車い す」，「ローラースケート等（スケートボード，一輪車 等を含む）」，「幼児用車（遊戯用の人力模擬車両）」， 「その他準歩行者（原付・自転車を引いている歩行者, 乳母車搭乗者及びそれを押寸歩行者等）」に分類されて いる. この中から電動車いす利用者が関連した交通事故 を抽出・集計し，手動車いすや一般歩行者等の他形態の 歩行者と比較することで，電動車いすの事故の特徵を把
握することとした

\section{(2) 分析対象}

交通事故統計における「電動車いす」には，手動の車 いすにモータを設置してジョイスティック等の操作で自 走が可能にしているいわゆる車い寸型のほかに，主に高 齢者が用いるハンドル型（シニアカー等）も含まれる

（図-1参照）。この2種の「電動車いす」は，使用者層 や使用方法が異なると想定されるが，双方ともにモータ で動く歩行者に準ずるものという点で搭乗型移動支援口 ボットと類似することから，ひとつにまとめて分析する こととした.

また，本研究で最終的に危険性を検討する搭乗型移動 支援ロボットには，前述したように様々なタイプがあり， 特性も異なるため, 危険性を比較考察するにあたっては 対象を絞る必要がある。そこで，ここでは主に図-2に示 すような立ち乗り型の搭乗型移動支援ロボットを想定す ることとする．電動車いすとの相違としては，表-1に示 すように重量や長さ・高さの他に，安定性（2輪と4輪）, 操作性（体重移動による操作とレバー・スイッチによる
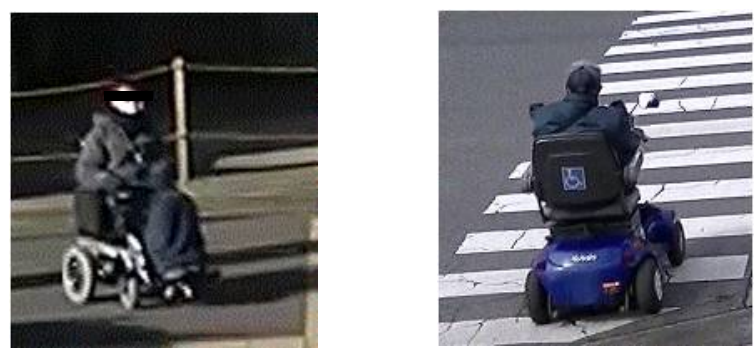

図-1 電動車いすの種類（左 : 車い寸型，右 : ハンドル型

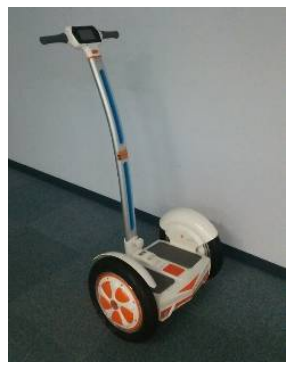

図-2＼cjkstart搭乗型移動支援ロボット例（立ち乗り型：AirWheel S3）

表-1 電動車い寸と搭乗型移動支援ロボットの諸元比較

\begin{tabular}{|l|l|l|}
\hline & \multicolumn{1}{|c|}{ 電動車いす規格※1 } & 搭乗型移動支援ロボット※2 \\
\hline 長さ & $120 \mathrm{~cm}$ 以下 & $50-60 \mathrm{~cm}$ 程度 \\
\hline 幅 & $70 \mathrm{~cm}$ 以下 & $60-65 \mathrm{~cm}$ 程度 \\
\hline 高さ & $109 \mathrm{~cm}$ 以下 & $130 \mathrm{~cm}$ 程度 \\
\hline 速度 & $6 \mathrm{~km} / \mathrm{h}$ 以下 & 最高 $12-20 \mathrm{~km}$ (制限可) \\
\hline 重量 & $80-115 \mathrm{~kg}$ 前後 & $23-47 \mathrm{~kg}$ \\
\hline 原動機 & 電動機のみ & 電動機 \\
\hline 他 & 鋭利な突出部がない & - \\
\hline
\end{tabular}

※1: 重量以外は道路交通法施行規則第一条「原動機を用いる歩行補助車 等の基準」による. 重量は主な市販品 (セニアカー, モンパル)を参照 ${ }^{13.14)}$ ※2: 立ち乗り型の主な市販品 (SegwayPTi2,AirWheelS3)の規格を参照 ${ }^{15,116)}$ 
操作），利用者層（電動車いすは高齢者や障がい者が利 用，搭乗型移動支援ロボットは健常者が多いと想定）等 があると考えられる．一方で，電動機で動く点，幅，速 度（搭乗型移動支援ロボットは公道走行時は $6 \mathrm{~km} / \mathrm{h}$ にな ることが想定される），片勾配に弱い点等は同質とみな せるため，危険性を検討するうえでは十分に参考になる と考えられる.

\section{4. 分析結果}

\section{(1) 電動車いす等の事故の現況}

表-2は，電動車い寸と手動車い寸，一般歩行者が関連 した事故及び全事故件数の推移（H10-29）を示したもの である. 本研究で定義する各形態（電動車いす，手動車 いす，一般歩行者）が「関連した事故」とは，事故の第 1当事者または第2当事者が該当する形態である事故とす る. そのため，第1当事者が電動車いすで第2当事者が一 般歩行者である事故は表中で重複して計上されることに なる．しかし，交通事故統計には歩行者同士の事故や歩 行者の単独事故は交通事故として計上されていないため, 重複計上されている事故はない。電動及び手動車いす の事故に着目してみると, 双方ともにH17-18をピークに 減少傾向となっており H29には約 5～6割程度まで減少し ている．H29における電動車いす関連事故と手動車いす 関連事故の発生件数を比較すると, 電動車いすの件数が 約2.6倍多くなっている. しかし，双方の交通量に差異 があるため, 事故件数が多いとしても危険性が高いとは 言い切れない.

表-3はH24-29の事故について事故内容別に集計したも のである. 電動車い寸関連事故が重傷以上の事故となる

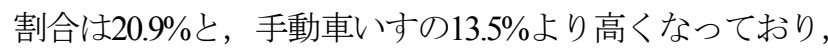
モーターの動力や車体の重量化等, 電動車いすの特性に より大きな怪我をする危険性が高くなることを示唆する 結果となった。電動車いすと手動車い寸重傷事故率（全 事故に占める死亡事故と重傷事故の割合）についてカイ 二乗検定を行った結果，当事者の形態と重傷故率の間に 有意な関連がみられ $\left(\chi^{2}=11.928, d f=1, p<.01, P h i=0.087\right)$, 残差分析の結果, 電動車いすは重大事故率が高く, 手動 車いすは低い傾向が確認された。このことから電動車い すの事故は手動車いすよりも重傷以上の事故になりやす いと言える.

\section{(2) 事故類型}

表-4は，各形態が関連した事故について，事故類型及 び当該形態の当事者の怪我の程度別に集計したものであ る. 怪我の程度については，各形態を利用する当事者本 人の怪我の程度となっており，怪我がない場合は集計か
表-2 電動車い寸関連事故等の発生傾向の推移（H10-29）

\begin{tabular}{|r|r|r|r|c|}
\hline & 件) \\
\hline 電動車いす & 手動車いす & 一般歩行者 & 全形態 \\
\hline H11 & 141 & 64 & 73,405 & 803,882 \\
\hline H12 & 165 & 64 & 75,852 & 850,371 \\
\hline H13 & 207 & 61 & 81,624 & 931,950 \\
\hline H14 & 209 & 74 & 80,965 & 947,253 \\
\hline H15 & 257 & 84 & 80,852 & 936,950 \\
\hline H16 & 271 & 74 & 78,954 & 948,281 \\
\hline H17 & 281 & 85 & 76,283 & 952,720 \\
\hline H18 & 258 & 112 & 73,704 & 887,346 \\
\hline H19 & 228 & 89 & 70,580 & 832,704 \\
\hline H20 & 232 & 81 & 68,469 & 766,394 \\
\hline H21 & 232 & 79 & 66,419 & 737,637 \\
\hline H22 & 258 & 93 & 66,558 & 725,924 \\
\hline H23 & 196 & 86 & 63,233 & 692,084 \\
\hline H24 & 215 & 87 & 60,207 & 665,157 \\
\hline H25 & 191 & 101 & 57,439 & 629,033 \\
\hline H26 & 182 & 95 & 53,706 & 573,842 \\
\hline H27 & 179 & 75 & 52,520 & 536,899 \\
\hline H28 & 155 & 76 & 49,081 & 499,201 \\
\hline H29 & 162 & 62 & 49,546 & 472,165 \\
\hline
\end{tabular}

※H10-29に発生し, 各形態が第1当事者か第2当事者であっ た事故を集計

表-3 電動車い寸等関連事故の事故内容（H24-29）

\begin{tabular}{|c|c|c|c|c|}
\hline & 電動車いす & 手動車いす & 一般歩行者 & 全形態 \\
\hline \multirow{2}{*}{ 死亡 } & 39 & 17 & 8,380 & 24,061 \\
\hline & $3.6 \%$ & $3.4 \%$ & $2.6 \%$ & $0.7 \%$ \\
\hline \multirow{2}{*}{ 重傷 } & 188 & 50 & 52,514 & 233,648 \\
\hline & $17.3 \%$ & $10.1 \%$ & $16.3 \%$ & $6.9 \%$ \\
\hline \multirow{2}{*}{ 軽傷 } & 857 & 429 & 261,605 & $3,118,588$ \\
\hline & $79.1 \%$ & $86.5 \%$ & $81.1 \%$ & $92.4 \%$ \\
\hline \multirow{2}{*}{ 合計 } & 1,084 & 496 & 322,499 & $3,376,297$ \\
\hline & $100.0 \%$ & $100.0 \%$ & $100.0 \%$ & $100.0 \%$ \\
\hline
\end{tabular}

表-4 事故類型と当該当事者の怪我の程度（H24-29）

\begin{tabular}{|c|c|c|c|c|c|c|}
\hline & \multicolumn{2}{|c|}{ 電動車いす } & \multicolumn{2}{|c|}{ 手動車いす } & \multicolumn{2}{|c|}{ 一般歩行者 } \\
\hline & $\begin{array}{c}\text { 全事故 } \\
\text { (全類型に } \\
\text { 占める割 } \\
\text { 合) }\end{array}$ & \begin{tabular}{|l} 
重傷以上 \\
(類型ごと \\
の重傷以 \\
上の割合)
\end{tabular} & \begin{tabular}{|c|} 
全事故 \\
(全類型に \\
占める割 \\
合)
\end{tabular} & $\begin{array}{l}\text { 重傷以上 } \\
\text { (類型ごと } \\
\text { の重傷以 } \\
\text { 上の割合) }\end{array}$ & \begin{tabular}{|c|} 
全事故 \\
(全類型に \\
占める割 \\
合)
\end{tabular} & $\begin{array}{l}\text { 重傷以上 } \\
\text { (類型ごと } \\
\text { の重傷以 } \\
\text { 上の割合) }\end{array}$ \\
\hline \multirow{2}{*}{$\begin{array}{c}\text { 歩道 } \\
\text { 通行中 }\end{array}$} & 20 & 1 & 8 & 0 & 4,671 & 609 \\
\hline & $1.9 \%$ & $(5.0 \%)$ & $1.6 \%$ & $(0.0 \%)$ & $1.5 \%$ & $(13.0 \%)$ \\
\hline \multirow{2}{*}{$\begin{array}{l}\text { 路側帯 } \\
\text { 通行中 }\end{array}$} & 9 & 4 & 6 & 1 & 6,083 & 636 \\
\hline & $0.8 \%$ & $(44.4 \%)$ & $1.2 \%$ & $(16.7 \%)$ & $1.9 \%$ & $(10.5 \%)$ \\
\hline \multirow{2}{*}{$\begin{array}{c}\text { 車道 } \\
\text { 通行中 }\end{array}$} & 100 & 41 & 49 & 12 & 28,757 & 4,188 \\
\hline & $9.3 \%$ & $(41.0 \%)$ & $0.0 \%$ & $(24.5 \%)$ & $8.9 \%$ & $(14.6 \%)$ \\
\hline \multirow{2}{*}{$\begin{array}{l}\text { その他 } \\
\text { 通行中 }\end{array}$} & 34 & 7 & 33 & 3 & 11,597 & 1,403 \\
\hline & $3.2 \%$ & $(20.6 \%)$ & $6.7 \%$ & $(9.1 \%)$ & $3.6 \%$ & $(12.1 \%)$ \\
\hline \multirow{2}{*}{$\begin{array}{c}\text { 横断歩道 } \\
\text { 横断中 }\end{array}$} & 306 & 40 & 94 & 13 & 100,934 & 17,916 \\
\hline & $28.5 \%$ & $(13.1 \%)$ & $19.2 \%$ & $(13.8 \%)$ & $31.4 \%$ & $(17.8 \%)$ \\
\hline \multirow{2}{*}{$\begin{array}{c}\text { 横断歩道 } \\
\text { 以外横断中 }\end{array}$} & 298 & 96 & 80 & 19 & 86,176 & 23,138 \\
\hline & $27.7 \%$ & $(32.2 \%)$ & $16.4 \%$ & $(23.8 \%)$ & $26.8 \%$ & $(26.8 \%)$ \\
\hline \multirow{2}{*}{$\begin{array}{c}\text { 路上で } \\
\text { 作業中等 }\end{array}$} & 18 & 4 & 19 & 1 & 15,733 & 4,032 \\
\hline & $1.7 \%$ & $(22.2 \%)$ & $3.9 \%$ & $(5.3 \%)$ & $4.9 \%$ & $(25.6 \%)$ \\
\hline \multirow{2}{*}{$\begin{array}{c}\text { 駐車場 } \\
\text { 出入部等 }\end{array}$} & 218 & 20 & 95 & 8 & 39,421 & 4,560 \\
\hline & $20.3 \%$ & $(9.2 \%)$ & $19.4 \%$ & $(8.4 \%)$ & $12.3 \%$ & $(11.6 \%)$ \\
\hline \multirow{2}{*}{$\begin{array}{l}\text { 駐車場 } \\
\text { 場内等 }\end{array}$} & 65 & 6 & 103 & 7 & 28,234 & 3,668 \\
\hline & $6.1 \%$ & $(9.2 \%)$ & $21.1 \%$ & $(6.8 \%)$ & $8.8 \%$ & $(13.0 \%)$ \\
\hline \multirow{2}{*}{ 列車事故 } & 6 & 6 & 2 & 2 & 183 & 178 \\
\hline & $0.6 \%$ & $(100.0 \%)$ & $0.4 \%$ & $(100.0 \%)$ & $0.1 \%$ & $(97.3 \%)$ \\
\hline \multirow{2}{*}{ 合計 } & 1,074 & 225 & 489 & 66 & 321,789 & 60,328 \\
\hline & $100.0 \%$ & $(20.9 \%)$ & $100.0 \%$ & $(13.5 \%)$ & $100.0 \%$ & $(18.7 \%)$ \\
\hline
\end{tabular}

※H24-291発生し, 各形態が第1当事者か第2当事者であった事故を集計 ※当該形態利用者の損傷程度のため, 事故内容の件数とは一致しない 
ら除外している．また，表-3における事故内容（死亡・ 重傷・軽傷）は，表-4の当該当事者の怪我の程度の分類 とは異なり，その事故において最も怪我の程度が重い当 事者での分類となっている. 例えば，電動車い寸利用者 が軽傷で相手の自転車が重傷であった場合は表-3では

「重傷」に分類され，表-4では「軽傷」に分類されるこ とになる，そのため，表-3と表-4の数值は若干のずれが ある．表中の歩道通行中の事故とは，歩道にて電動車い 寸等と自動車等が対面通行若しくは背面通行していた状 態で発生した事故となっている. どの形態であっても横 断中の事故が多くなっているが，手動車い寸は他の形態 と比較して駐車場場内等での事故の割合が多くなってい るのがわかる.

電動車い寸の重傷以上の事故の割合については，車道 通行中や横断歩道以外を横断中の事故類型において高く なっている. 特に, 電動車いすと自動車との動線が交わ るわけでもない「車道や路側帯通行中」の事故の重傷以 上の事故の割合は $40 \%$ 以上となっており注意が必要であ る. 列車事故も件数は少ないが重大な事故になりやすい ことが特筆される.

\section{（3）当該当事者の年齢層と違反状況}

表-5は, 各形態の関連した事故について, 当該当事者 の年齢層及び怪我の程度別に集計したものである.

電動車い寸関連事故の全事故の構成率からは，手動車 い寸や一般歩行者と比較して，70歳以上の高齢者が多い ことがわかる，これは，電動車い寸に含まれるハンドル 型が高齢者向けに販売されていることが影響していると 考えられる. また, 性別で見てみると, 電動・手動とも に多くの年代で男性の割合が高くなっていた. しかし，

80歳以上では男性が17.7に対して女性が19.4\%と高いのは, 女性の方が平均寿命が長いことも影響していると考えら れる.

事故にあった場合に重傷以上であるかどうかを各年齢 層別にみてみると, 電動車い寸は80歳以上の年齢層で重 傷以上になる割合が特に多かった。一般歩行者でも同様 であったが，こちらは70〜79歳でも重傷以上の割合が 30\%前後と高くなっており異なる傾向となっている．ま た，電動車い寸関連事故の死亡者数 39 人のうち 20 人が 80 歳以上の男性, 13 人が 80 歳以上の女性と, 電動車い寸利 用中に死亡している者の約 $85 \%$ は 80 歳以上の高齢者で占 められていた。重傷以上となった当事者の損傷部位を 見てみると, すべての形態で頭部が多く25\%前後となっ ていた. 死亡のみに限定してみると，頭部損傷の占める 割合がさらに高くなった。 それに加え電動車い寸の場合 は，重傷以上の事故では胸部損傷の占める割合も $21.3 \%$ （一般歩行者 $9.4 \%$ ） と高くなっていた.

表-6の当事者の違反状況については, 電動車い寸利用
表-5 当該当事者の年齢層と怪我の程度（H24-29）

\begin{tabular}{|c|c|c|c|c|c|c|c|}
\hline & \multicolumn{2}{|c|}{ 電動車いす } & \multicolumn{2}{|c|}{ 手動車いす } & \multicolumn{2}{|c|}{ 一般歩行者 } \\
\hline & & $\begin{array}{c}\text { 全事故 } \\
\text { (全年齢層 } \\
\text { に占める } \\
\text { 割合) } \\
\end{array}$ & $\begin{array}{l}\text { 重傷以上 } \\
\text { (年歯層ご } \\
\text { 亡の重傷以 } \\
\text { 上の割合) } \\
\end{array}$ & \begin{tabular}{|c|} 
全事故 \\
(全年齢層 \\
に占める \\
割合) \\
\end{tabular} & \begin{tabular}{|c|} 
重傷以上 \\
(年齢層ご \\
との重傷以 \\
上の割合) \\
\end{tabular} & \begin{tabular}{|c|} 
全事故 \\
(全年齢層 \\
に占める \\
割合) \\
\end{tabular} & \begin{tabular}{|c} 
重傷以上 \\
(年齢層こ \\
との重傷以 \\
上の割合) \\
\end{tabular} \\
\hline \multirow{2}{*}{\multicolumn{2}{|c|}{ 1-19歳 }} & 5 & 0 & 9 & 1 & 57,776 & 7,282 \\
\hline & & $0.5 \%$ & $(0.0 \%)$ & $1.8 \%$ & $(11.1 \%)$ & $18.0 \%$ & $(12.6 \%)$ \\
\hline \multirow{4}{*}{ 徒 } & \multirow{2}{*}{ 男 } & 41 & 4 & 60 & 5 & 37,794 & 3,486 \\
\hline & & $3.8 \%$ & $(9.8 \%)$ & $12.3 \%$ & $(8.3 \%)$ & $11.7 \%$ & $(9.2 \%)$ \\
\hline & 女 & 26 & 2 & 15 & 1 & 27,317 & 2,059 \\
\hline & & $2.4 \%$ & $(7.7 \%)$ & $3.1 \%$ & $.7 \%)$ & $5 \%$ & $(7.5 \%)$ \\
\hline & 田 & 47 & 0 & 56 & 4 & 23,437 & 2,761 \\
\hline 掹 & 男 & $4.4 \%$ & $(6.4 \%)$ & $11.5 \%$ & $(7.1 \%)$ & $7.3 \%$ & $(11.8 \%)$ \\
\hline & 女 & 30 & 1 & 18 & & 15,588 & 1,514 \\
\hline & & $2.8 \%$ & $(3.3 \%)$ & $3.7 \%$ & $6 \%)$ & $8 \%$ & $(9.7 \%)$ \\
\hline & \multirow{2}{*}{ 男 } & 83 & 5 & $y$ & & 20,117 & 3,248 \\
\hline & & $7.7 \%$ & $(6.0 \%)$ & $1.2 \%$ & $(14.5 \%)$ & $6.3 \%$ & $(16.1 \%)$ \\
\hline & \multirow{2}{*}{ 女 } & 38 & 3 & 22 & 1 & 15,256 & 2,527 \\
\hline & & $3.5 \%$ & $(7.9 \%)$ & $4.5 \%$ & $(4.5 \%)$ & $4.7 \%$ & $(16.6 \%)$ \\
\hline & \multirow{2}{*}{ 男 } & 103 & 15 & 63 & 8 & 21,371 & 4,916 \\
\hline & & $9.6 \%$ & $(14.6 \%)$ & $2.9 \%$ & $(12.7 \%)$ & $6.6 \%$ & $(23.0 \%)$ \\
\hline & \multirow{2}{*}{ t } & 54 & 9 & 33 & 4 & 22,175 & 5,201 \\
\hline & & $5.0 \%$ & $(16.7 \%)$ & $6.7 \%$ & $(12.1 \%)$ & $6.9 \%$ & $(23.5 \%)$ \\
\hline \multirow{4}{*}{ 哺 } & \multirow{2}{*}{ 男 } & 133 & 19 & 45 & 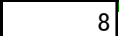 & 18,151 & 5,255 \\
\hline & & $12.4 \%$ & (14.3\%) & $9.2 \%$ & $(17.8 \%)$ & $5.6 \%$ & $(29.0 \%)$ \\
\hline & \multirow{2}{*}{ 女 } & 116 & 17 & 28 & 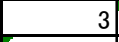 & 29,961 & 9,278 \\
\hline & & $10.8 \%$ & $(14.7 \%)$ & $5.7 \%$ & $(10.7 \%)$ & $9.3 \%$ & $(31.0 \%)$ \\
\hline \multirow[t]{4}{*}{$\perp$} & \multirow{2}{*}{ 男 } & 190 & 71 & 23 & 6 & 10,063 & 3,806 \\
\hline & & $17.7 \%$ & $(37.4 \%)$ & $4.7 \%$ & $(26.1 \%)$ & $3.1 \%$ & $(37.8 \%)$ \\
\hline & \multirow{2}{*}{ 女 } & 208 & 76 & 62 & 16 & 22,783 & 8,995 \\
\hline & & $19.4 \%$ & $(36.5 \%)$ & $12.7 \%$ & $(25.8 \%)$ & $7.1 \%$ & (39.5\%) \\
\hline \multirow{2}{*}{\multicolumn{2}{|c|}{ 合計 }} & 1,074 & 225 & 489 & 66 & 321,789 & 60,328 \\
\hline & & $100.0 \%$ & $(20.9 \%)$ & $100.0 \%$ & $(13.5 \%)$ & $100.0 \%$ & $(18.7 \%)$ \\
\hline
\end{tabular}
※H24-291に発生し, 各形態が第1当事者か第2当事者であった事故を集計 ※当該形態利用者の損偒程度のため, 事故内容の件数とは一致しない

表-6 当該当事者の違反状況と怪我の程度（H24-29）

\begin{tabular}{|c|c|c|c|c|c|c|}
\hline & \multicolumn{2}{|c|}{ 電動車いす } & \multicolumn{2}{|c|}{ 手動車いす } & \multicolumn{2}{|c|}{ 一般歩行者 } \\
\hline & $\begin{array}{c}\text { 全事故 } \\
\text { （全年違反 } \\
\text { に占める } \\
\text { 割合） }\end{array}$ & $\begin{array}{l}\text { 重傷以上 } \\
\text { (違反ごと } \\
\text { の重傷以 } \\
\text { 上の割合) }\end{array}$ & $\begin{array}{c}\text { 全事故 } \\
\text { (全年違反 } \\
\text { に占める } \\
\text { 割合) } \\
\end{array}$ & \begin{tabular}{|l|} 
重傷以上 \\
(違反ごと \\
の重傷以 \\
上の割合) \\
\end{tabular} & $\begin{array}{c}\text { 全事故 } \\
\text { (全年違反 } \\
\text { に占める } \\
\text { 割合) }\end{array}$ & $\begin{array}{l}\text { 重傷以上 } \\
\text { (違反ごと } \\
\text { の重傷以 } \\
\text { 上の割合) }\end{array}$ \\
\hline \multirow{2}{*}{ 信号無視 } & 27 & 6 & 8 & 4 & 6,799 & 2,686 \\
\hline & $2.5 \%$ & $(22.2 \%)$ & $1.6 \%$ & $(50.0 \%)$ & $2.1 \%$ & $(39.5 \%)$ \\
\hline \multirow{2}{*}{ 左側通行 } & 35 & 16 & - & 4 & 6,604 & 1,017 \\
\hline & $3.3 \%$ & $(45.7 \%)$ & $1.4 \%$ & $(57.1 \%)$ & $2.1 \%$ & $(15.4 \%)$ \\
\hline \multirow{2}{*}{ 車道通行等 } & 28 & 17 & 18 & 5 & 3,695 & 943 \\
\hline & $2.6 \%$ & $(60.7 \%)$ & $3.7 \%$ & $(27.8 \%)$ & $1.1 \%$ & $(25.5 \%)$ \\
\hline \multirow{2}{*}{$\begin{array}{c}\text { 車両前後で } \\
\text { の横断 }\end{array}$} & 63 & 21 & 22 & 8 & 14,205 & 4,578 \\
\hline & $5.9 \%$ & $(33.3 \%)$ & $4.5 \%$ & $(36.4 \%)$ & $4.4 \%$ & $(32.2 \%)$ \\
\hline \multirow{2}{*}{ 斜め横断 } & 22 & 9 & 4 & 2 & 4,602 & 1,308 \\
\hline & $.0 \%$ & $(40.9 \%)$ & $0.8 \%$ & $(50.0 \%)$ & $1.4 \%$ & $(28.4 \%)$ \\
\hline \multirow{2}{*}{$\begin{array}{c}\text { 横断歩道外 } \\
\text { 横断等 } \\
\end{array}$} & 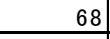 & 27 & 17 & 4 & 1,073 & 7,013 \\
\hline & $6.3 \%$ & $(39.7 \%)$ & $3.5 \%$ & $(23.5 \%)$ & $6.5 \%$ & $(33.3 \%)$ \\
\hline \multirow{2}{*}{ 飛出し } & 12 & 4 & 3 & 2 & 18,868 & 3,541 \\
\hline & $1.1 \%$ & $(33.3 \%)$ & $0.6 \%$ & $(66.7 \%)$ & $5.9 \%$ & $(18.8 \%)$ \\
\hline \multirow{2}{*}{ 踏切不注意 } & 5 & 5 & 2 & 2 & 167 & 152 \\
\hline & $0.5 \%$ & $(100.0 \%)$ & $0.4 \%$ & $(100.0 \%)$ & $0.1 \%$ & $(91.0 \%)$ \\
\hline \multirow{2}{*}{ その他違反 } & 48 & 8 & 15 & 4 & 18,775 & 4,687 \\
\hline & $4.5 \%$ & $(16.7 \%)$ & $3.1 \%$ & $(26.7 \%)$ & $5.8 \%$ & $(25.0 \%)$ \\
\hline \multirow{2}{*}{ 不明 } & 1 & 1 & 0 & 0 & 983 & 575 \\
\hline & $0.1 \%$ & $(100.0 \%)$ & $0.0 \%$ & - & $0.3 \%$ & $(58.5 \%)$ \\
\hline \multirow{2}{*}{ 違反なし } & 765 & 111 & 393 & 31 & 226,018 & 33,828 \\
\hline & $71.2 \%$ & $(14.5 \%)$ & $80.4 \%$ & $(7.9 \%)$ & $70.2 \%$ & $(15.0 \%)$ \\
\hline \multirow{2}{*}{ 合計 } & 1,074 & 225 & 489 & 66 & 321,789 & 60,328 \\
\hline & $100.0 \%$ & $(20.9 \%)$ & $100.0 \%$ & $(13.5 \%)$ & $100.0 \%$ & $(18.7 \%)$ \\
\hline
\end{tabular}

※H24-291発生し, 各形態が第1当事者か第2当事者であった事故を集計 ※当該形態利用者の損傷程度のため, 事故内容の件数とは一致しない 
者は一般歩行者と比較して飛出しが少なくなっていたが, 特徵的に多くなっているものは確認できなかった。 しか し，当事者の怪我の程度を見てみると，電動車い寸利用 者が左側通行や車道通行等の違反をすると重傷以上の事 故となる割合が高くなることがわかる．また，横断中の 事故はどの形態でも重傷以上となる割合が $30 \%$ 程度と高 くなっていた.

\section{(4) 相手当事者}

表-7は，当該当事者の事故の相手を計上したものであ る. 各形態間でどのような相手との事故が多くなるかを 比較してみると, 当該当事者が電動車い寸利用者であっ た場合は，相手当事者が軽自動車である割合が $36.3 \%$, 手動車いすや一般歩行者であった場合と比較して高くな っていた．重傷以上の割合についても，電動車い寸は対 軽自動車の事故において高くなっている．相手当事者が 事故を起こした人的な要因としては, 当該当事者の形態 にかかわらず発見の遅れによるものが多かった．ただ, 当該当事者が座っているために他者から見つけにくいと 考えられる電動車い寸や手動車い寸の場合は, 発見遅れ の割合は $87.8 \% ， 90.6 \%$ と一般歩行者の $80.5 \%$ よりも若干 高くなっていた.

\section{(5) 事故発生地点}

事故発生地点の人口集積と道路幅員，当該当事者の怪 我の程度別の集計結果を表-8に示す. 事故件数は, どの

表-7 相手当事者と当該当事者の怪我の程度（H24-29）

\begin{tabular}{|c|c|c|c|c|c|c|}
\hline & \multicolumn{2}{|c|}{ 電動車いす } & \multicolumn{2}{|c|}{ 手動車いす } & \multicolumn{2}{|c|}{ 一般歩行者 } \\
\hline & $\begin{array}{c}\text { 全事故 } \\
\text { （全相手に } \\
\text { 占める割 } \\
\text { 合） }\end{array}$ & $\begin{array}{l}\text { 重傷以上 } \\
\text { (相手ごと } \\
\text { の重傷以 } \\
\text { 上の割合) }\end{array}$ & 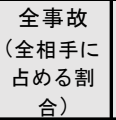 & $\begin{array}{l}\text { 重傷以上 } \\
\text { (相手ごと } \\
\text { の重傷以 } \\
\text { 上の割合) }\end{array}$ & $\begin{array}{c}\text { 全事故 } \\
\text { (全相手に } \\
\text { 占める割 } \\
\text { 合) }\end{array}$ & $\begin{array}{l}\text { 重傷以上 } \\
\text { (相手ごと } \\
\text { の重傷以 } \\
\text { 上の割合) }\end{array}$ \\
\hline \multirow{2}{*}{$\begin{array}{l}\text { 大中型 } \\
\text { 貨物車 } \\
\text { 乗用車 }\end{array}$} & 52 & 18 & 16 & 5 & 9,608 & 2,959 \\
\hline & $4.8 \%$ & $(34.6 \%)$ & $3.3 \%$ & $(31.3 \%)$ & $3.0 \%$ & $(30.8 \%)$ \\
\hline \multirow{2}{*}{$\begin{array}{c}\text { 普通 } \\
\text { 貨物車 }\end{array}$} & 62 & 13 & 31 & 1 & 15,265 & 3,132 \\
\hline & $5.8 \%$ & $(21.0 \%)$ & $6.3 \%$ & $(3.2 \%)$ & $4.7 \%$ & $(20.5 \%)$ \\
\hline \multirow{2}{*}{$\begin{array}{c}\text { 普通 } \\
\text { 乗用車 }\end{array}$} & 489 & 63 & 241 & 33 & 158,598 & 27,400 \\
\hline & $45.5 \%$ & $(12.9 \%)$ & $49.3 \%$ & $(13.7 \%)$ & $49.3 \%$ & $(17.3 \%)$ \\
\hline \multirow{2}{*}{ 軽自動車 } & 390 & 116 & 152 & 20 & 92,766 & 20,272 \\
\hline & $36.3 \%$ & $(29.7 \%)$ & $31.1 \%$ & $(13.2 \%)$ & $28.8 \%$ & (21.9\%) \\
\hline \multirow{2}{*}{$\begin{array}{c}\text { 自動二輪 } \\
\text { 原付 }\end{array}$} & 28 & 7 & 24 & 4 & 17,824 & 3,294 \\
\hline & $2.6 \%$ & $(25.0 \%)$ & $4.9 \%$ & $(16.7 \%)$ & $5.5 \%$ & $(18.5 \%)$ \\
\hline \multirow{2}{*}{ 自転車等 } & 24 & 2 & 14 & 0 & 13,632 & 1,771 \\
\hline & $2.2 \%$ & $(8.3 \%)$ & $2.9 \%$ & $(0.0 \%)$ & $4.2 \%$ & $(13.0 \%)$ \\
\hline \multirow{2}{*}{ 特殊車両 } & 0 & 0 & 0 & 0 & 388 & 159 \\
\hline & $0.0 \%$ & - & $0.0 \%$ & - & $0.1 \%$ & $(41.0 \%)$ \\
\hline \multirow{2}{*}{ 列車 } & 6 & 6 & 3 & 2 & 200 & 188 \\
\hline & $0.6 \%$ & $(100.0 \%)$ & $0.6 \%$ & $(66.7 \%)$ & $0.1 \%$ & $(94.0 \%)$ \\
\hline \multirow{2}{*}{ 不明等 } & 23 & 0 & 8 & 1 & 13,508 & 1,153 \\
\hline & $2.1 \%$ & $(0.0 \%)$ & $1.6 \%$ & $(12.5 \%)$ & $4.2 \%$ & $(8.5 \%)$ \\
\hline \multirow{2}{*}{ 合計 } & 1,074 & 225 & 489 & 66 & 321,789 & 60,328 \\
\hline & $100.0 \%$ & $(20.9 \%)$ & $100.0 \%$ & $(13.5 \%)$ & $100.0 \%$ & $(18.7 \%)$ \\
\hline
\end{tabular}

※H24-29に発生し, 各形態が第1当事者か第2当事者であった事故を集計 ※当該形態利用者の損傷程度のため, 事故内容の件数とは一致しない ※ミニカーは軽自動車, 準中型貨物車は普通貨物車 (H29より), 準中型乗用 車は普通乗用車(H29より)に含む
形態であっても人口集積が高い地域で多くなっている. 一般的に人口集積が高いと交通量も多くなるため交通事 故が多くなるのは当然とも考えられる，一方で，電動車 い寸関連事故は, 手動車い寸や一般歩行者と比較すると 非市街地での発生割合が高くなっており, 手動車い寸 $14.3 \%$ ，一般歩行者 $16.0 \%$ に対して $26.2 \%$ であった.

当該当事者の重傷以上の割合については，市街地より も自動車の速度の出しや寸い非市街地において高くなる と想定できるが，電動車い寸関連事故ではこの傾向が強 くなっていた.この点についてさらに詳細に見てみると， 非市街地の中での道路幅員が5.5 13.0mの中程度の道路 において重傷以上の事故の割合が $40.3 \%$ と特に高い，そ れ以上の幅員の道路については, サンプル数が少なく比 較ができなかった。

\section{(6) 事故発生地点の詳細}

交通事故統計には事故発生地点の緯度経度が記録され ている.ここでは, 特徵的であった電動車い寸関連事故 の発生地点の状況を詳細に見てみる。まず，表-4では車 道走行中に重傷以上となる割合が高いことが分かった。

表-8 事故発生地点の人口集積と道路幅員及び当該当事者の怪 我の程度（H24-29）

\begin{tabular}{|c|c|c|c|c|c|c|c|}
\hline & \multicolumn{2}{|c|}{ 電動車いす } & \multicolumn{2}{|c|}{ 手動車いす } & \multicolumn{2}{|c|}{ 一般歩行者 } \\
\hline & & $\begin{array}{c}\text { 全事故 } \\
\text { (全要因に } \\
\text { 占める割 } \\
\text { 合) }\end{array}$ & $\begin{array}{l}\text { 重傷以上 } \\
\text { (要因ごと } \\
\text { の重傷以 } \\
\text { 上の割合) }\end{array}$ & $\begin{array}{c}\text { 全事故 } \\
\text { (全要因に } \\
\text { 占める割 } \\
\text { 合) } \\
\end{array}$ & $\begin{array}{l}\text { 重傷以上 } \\
\text { (要因ごと } \\
\text { の重傷以 } \\
\text { 上の割合) } \\
\end{array}$ & $\begin{array}{c}\text { 全事故 } \\
\text { (全要因に } \\
\text { 占める割 } \\
\text { 合) }\end{array}$ & $\begin{array}{l}\text { 重傷以上 } \\
\text { (要因ごと } \\
\text { の重傷以 } \\
\text { 上の割合) } \\
\end{array}$ \\
\hline \multirow{8}{*}{ 음 } & \multirow{2}{*}{$\begin{array}{l}\text { 道路幅員 } \\
5.5 \mathrm{~m} \text { 未満 }\end{array}$} & 92 & 12 & 72 & 5 & 36076 & 3931 \\
\hline & & $8.6 \%$ & $3.0 \%)$ & $14.7 \%$ & $(6.9 \%)$ & $11.2 \%$ & $(10.9 \%)$ \\
\hline & \multirow{2}{*}{$\begin{array}{l}\text { 道路幅員 } \\
13 \mathrm{~m} \text { 末満 }\end{array}$} & 275 & 38 & 115 & 19 & 95187 & 16469 \\
\hline & & $25.6 \%$ & $3.8 \%)$ & $23.5 \%$ & $(16.5 \%)$ & $29.6 \%$ & $(17.3 \%)$ \\
\hline & \multirow{2}{*}{\begin{tabular}{|l} 
道路幅員 \\
$13 \mathrm{~m}$ 上上 \\
\end{tabular}} & 79 & 12 & 40 & 5 & 30383 & 6275 \\
\hline & & $7.4 \%$ & $(15.2 \%)$ & $8.2 \%$ & $(12.5 \%)$ & $9.4 \%$ & $(20.7 \%)$ \\
\hline & \multirow{2}{*}{$\begin{array}{l}\text { 駐車場 } \\
\text { 広場等 }\end{array}$} & 33 & 5 & 56 & 3 & 14887 & 1698 \\
\hline & & $3.1 \%$ & 2\%) & $.5 \%$ & $4 \%$ & $4.6 \%$ & $0.0 \%)$ \\
\hline \multirow{6}{*}{ 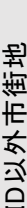 } & \multirow{2}{*}{$\begin{array}{l}\text { 道路幅員 } \\
5.5 \mathrm{~m} \text { 未満 } \\
\end{array}$} & 58 & 11 & 33 & 7 & 17615 & 2691 \\
\hline & & $5.4 \%$ & $(19.0 \%)$ & $6.7 \%$ & $(21.2 \%)$ & $5.5 \%$ & $(15.3 \%)$ \\
\hline & \multirow{2}{*}{$\begin{array}{l}\text { 道路幅員 } \\
13 \mathrm{~m} \text { 未満 }\end{array}$} & 202 & 44 & 55 & 10 & 52456 & 11582 \\
\hline & & $18.8 \%$ & $(21.8 \%)$ & $11.2 \%$ & $(18.2 \%)$ & $16.3 \%$ & $(22.1 \%)$ \\
\hline & \multirow{2}{*}{$\begin{array}{l}\text { 道路幅員 } \\
13 \mathrm{~m} \text { 以上 }\end{array}$} & 28 & 5 & 12 & 1 & 10660 & 2649 \\
\hline & & $2.6 \%$ & 9\%) & $2.5 \%$ & $3 \%)$ & $3.3 \%$ & $(24.8 \%)$ \\
\hline \multirow[t]{2}{*}{$\overrightarrow{0}$} & \multirow{2}{*}{$\begin{array}{l}\text { 駐車場 } \\
\text { 広場等 }\end{array}$} & 26 & 2 & 36 & 3 & 13108 & 1679 \\
\hline & & $2.4 \%$ & $7 \%$ ) & $7.4 \%$ & $3 \%$ & $4.1 \%$ & $(0.0 \%)$ \\
\hline \multirow{2}{*}{\multicolumn{2}{|c|}{$\begin{array}{l}\text { 道路幅員 } \\
5.5 \mathrm{~m} \text { 末満 } \\
\end{array}$}} & 54 & 15 & 9 & 1 & 11448 & 2380 \\
\hline & & $5.0 \%$ & $(27.8 \%)$ & $1.8 \%$ & $(11.1 \%)$ & $3.6 \%$ & $(20.8 \%)$ \\
\hline \multirow{6}{*}{ 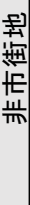 } & \multirow{2}{*}{$\begin{array}{l}\text { 道路幅員 } \\
13 \mathrm{~m} \text { 未満 } \\
\end{array}$} & 191 & 77 & 24 & 9 & 26100 & 8205 \\
\hline & & $17.8 \%$ & $(40.3 \%)$ & $4.9 \%$ & $(37.5 \%)$ & $8.1 \%$ & $(31.4 \%)$ \\
\hline & & 15 & 3 & 0 & 0 & 3379 & 1094 \\
\hline & & $1.4 \%$ & $(20.0 \%)$ & $0.0 \%$ & - & $1.1 \%$ & $(32.4 \%)$ \\
\hline & \multirow{2}{*}{$\begin{array}{l}\text { 駐車場 } \\
\text { 広場等 }\end{array}$} & 21 & 1 & 37 & 3 & 10490 & 1675 \\
\hline & & $2.0 \%$ & $(4.8 \%)$ & $7.6 \%$ & $(8.1 \%)$ & $3.3 \%$ & $(0.0 \%)$ \\
\hline \multirow{2}{*}{\multicolumn{2}{|c|}{ 合計 }} & 1,074 & 225 & 489 & 66 & 321,789 & 60,328 \\
\hline & & $100.0 \%$ & $(20.9 \%)$ & $100.0 \%$ & $(13.5 \%)$ & $100.0 \%$ & $(18.7 \%)$ \\
\hline
\end{tabular}

※ $24-291$ 発生し, 各形態が第1当事者か第2当事者であった事故を集計 ※当該形態利用者の損傷程度のため, 事故内容の件数とは一致しない ※市街地:道路に沿って $500 \mathrm{~m}$ 以上にわたって住宅·事業所等が連立し, その地域 の80\%以上となっているいわゆる市街地的形態の地域. DID : 市街地のうち国勢調 査に基づき設定された人口集中地区. 非市街地:それ以外の地域 ※交差点部は広幅員の方の道路に分類 
そこで, H2429の電動車い寸関連事故において, 歩道が あるにもかかわらず，車道を走行中（横断中を除く）に 重傷以上の事故となっている22件について, Googleス卜 リートビューを利用して目視により現地状況を確認した。 その結果, 場所の確認ができた21件中14件については歩 道の急な段差や車止等の障害物，狭盆な歩道幅員，歩 道が途中で途切れているといった状況が確認できた（図 -3〜図-5参照）。これらの理由のため, 電動車い寸が車 道を走行せざるを得なかっただろうと推察された。電動 車い寸の歩道走行が可能な道路環境であったとしても, 歩道上の駐車車両等により車道を走行しなくてはならな いような状況も発生すると考えられる.

発生するとほぼ重大事故となる列車事故については, 6件中4件が交通量の少ない規模の小さな踏切で発生して いた. 歩行者自転車専用の踏み切りで，段差や勾配のき つい思われる箇所もあった（図-6参照）。そのような 踏切では転倒, 脱輪等による立往生が発生しや寸く, 通 行人による救助も期待できないため危険性が高いと感じ られた。

\section{5. 考察}

電動車い寸関連事故等の交通事故統計分析からは，電 動車い寸が車道走行時に重傷以上の事故になりやすこと がわかった.これについて事故発生地点の詳細を見てみ ると, 歩道の段差や障害物, 狭幅員, 歩道の途中断絶と いった歩道を走行できない事情により仕方なく車道を走 行して事故に遭遇した事案も多いと考えられた。筆者ら が千葉県柏市内において，電動車い寸が歩道があるにも かかわらず車道を走行（平成30年5月に確認）している 箇所を調査したところ, 狭隘・障害物・側溝蓋の欠落等 の電動車い寸での走行が難しい劣悪な歩道環境であるこ とが分かった（図-7〜図-10参照）。本来であれば，走 行に適さない通行路を改良していくことが必要であるが, 全ての道路において早急に対応することは難しい，以上 のことから，搭乗型移動支援ロボットを導入するうえで は，これらの障壁がない道路ネットワークを走行路とし て指定しておくことも有用である考えられた（搭乗型移 動支援ロボットの通行に障壁のない幅員が十分で段差等 のない道路を事前に点検し, 通行に適した道路に標識・ 標示等をしておく）。これにより，電動車い寸や搭乗 型移動支援ロボットが道路上で強制的に危険な状況にお かれてしまうことを回避するとともに，道路改良の必要 な箇所が明確になると考えられる.

手動車い寸は, 電動車い寸とは異なり駐車場場内での 事故が多くなっていた。これは, 駐車場にて自動車から 手動車い寸に乗り換えて，駐車場内を移動しているとき

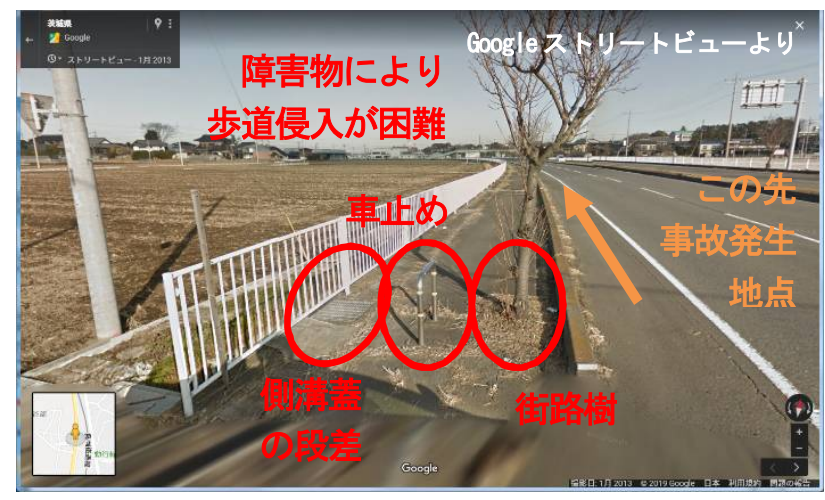

図-3 車道での事故発生地点近辺にある歩道上の障害物

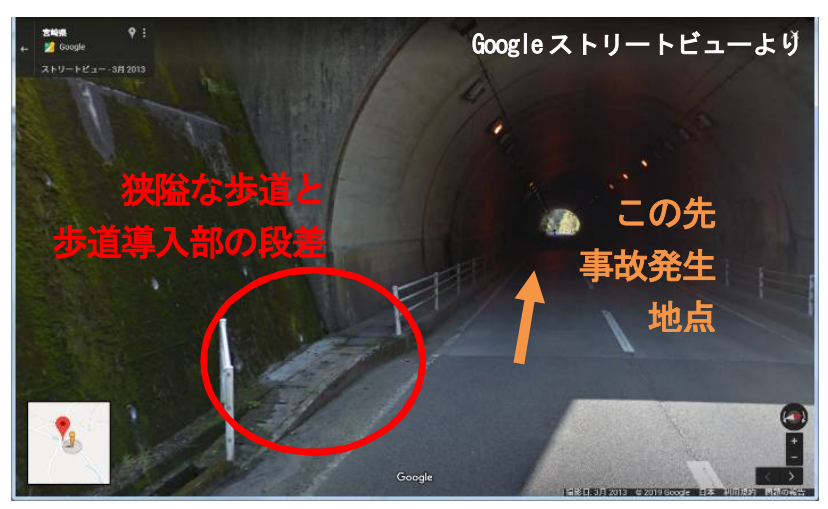

図-4 車道での事故発生地点近辺の狭隘歩道と導入部の段差

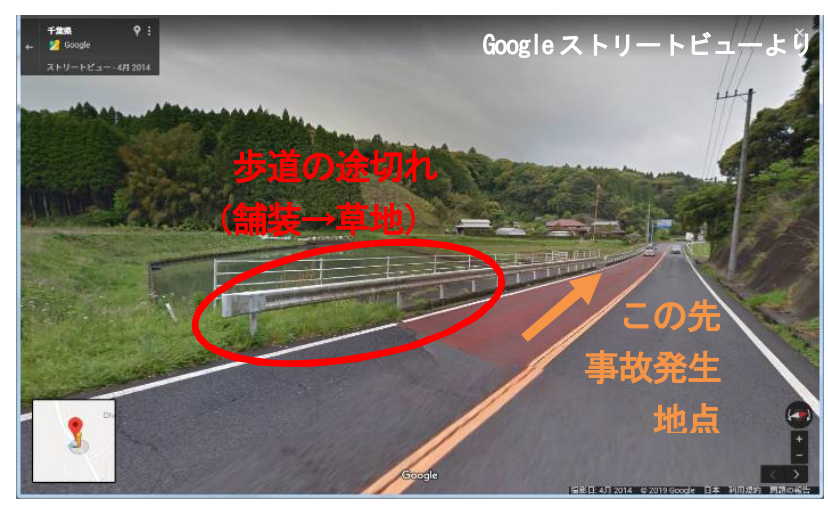

図-5 車道での事故発生地点近辺の歩道の途切れ

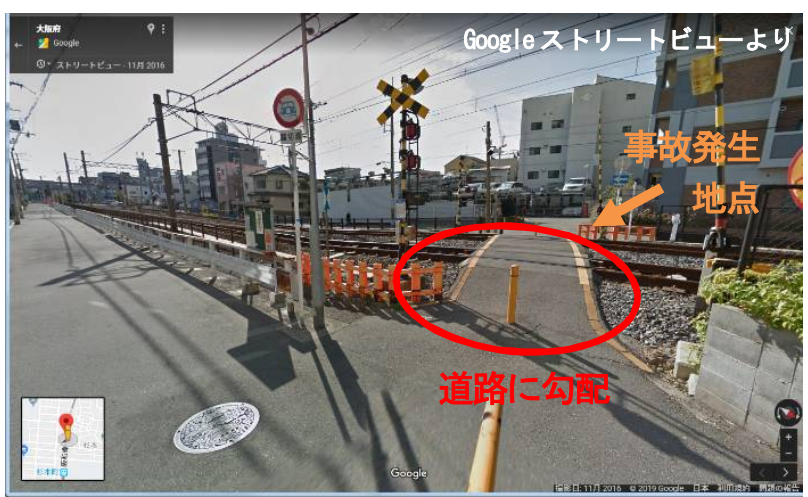

図-6 踏切での事故発生地点 


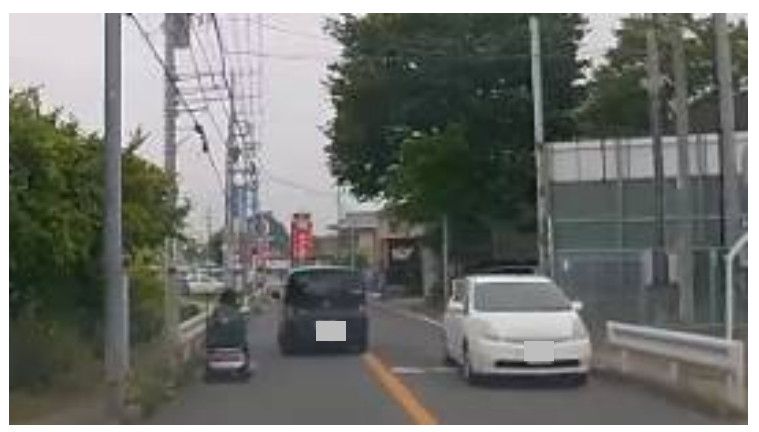

図-7 歩道があるにもかかわらず車道を走行する電動車いす

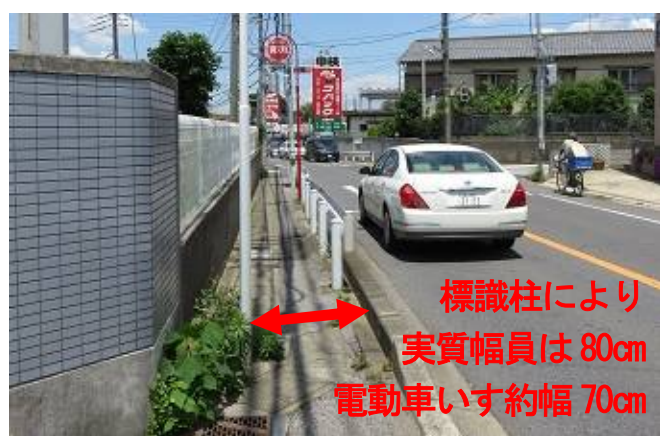

図-8 障害物による歩道の狭险化

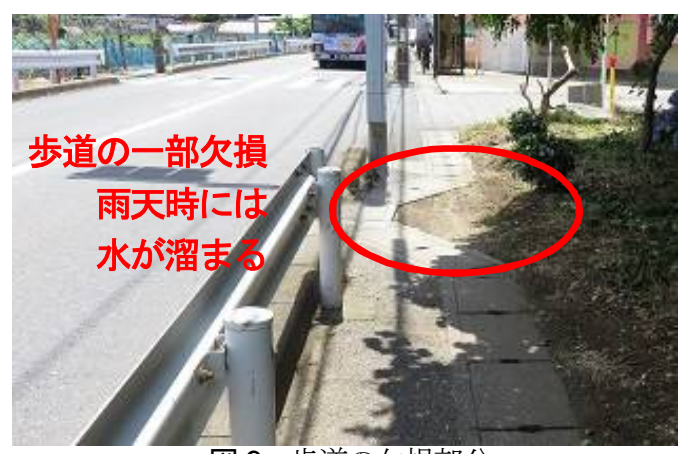

図-9 歩道の欠損部分

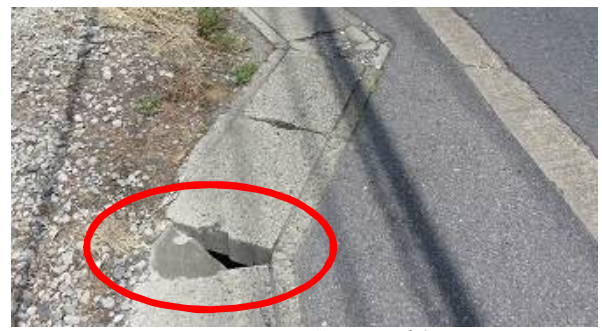

図-10 側溝蓋の破損

に事故にあっていると考えられる，車い寸利用者は座っ ているため自動車からも発見しにくい．電動車い寸で同 様な傾向にはならなかった理由は，電動車い寸に多く含 まれるハンドル型が自動車に乗せて，駐車場で乗り換え る様な用途では使われにくいからだと考えられる。一方 で，駐車場出入部では，手動車い寸と同様に電動車い寸 の事故も多くなっていた．座って搭乗するタイプの搭乗 型移動支援ロボットには周囲に存在を示寸ためのパーツ をつけておくことや駐車場内での搭乗を控えてもらうこ とも事故防止に有効だと考えられる.
電動車い寸関連事故の利用者に着目してみると，70歳 以上の高齢者が多くなっていた．また，非市街地での事 故が多くなっていたことから，地方部の起伏のあるよう な地域で, 高齢者向けのハンドル型の電動車い寸が普及 していると推察された．非市街地において普及すること で，郊外部において保有されることの多い軽自動車 ${ }^{10)}$ と の事故も多くなっていると考えられる．また，体力の低 い高齢者の利用者が多くなることで，重傷以上の事故の 割合が多くなる要因にもなっていると矁念される.

次に手動車い寸と比較した電動車いすの事故リスクに ついて考えてみる. H28の車いすの販売台数の統計值 ${ }^{11}$ を見てみると，手動車い寸は226,234台，電動車い寸は 13,166台となっており, 手動車い寸の販売台数が約17倍 も多くなっている。 しかし，H2429の交通事故件数は電 動車い寸関連事故が1,084件と手動車い寸関連事故の496 件の約2倍となっている．ここからは，販売台数が少な いにもかかわらず交通事故件数が多い電動車い寸が圧倒 的に危険であるように思われるが，手動車い寸は室内で 用いられることも多いため, 販売台数から屋外で発生す る交通事故の事故リスクを比較するのは難しいと考えら れる，そこで，車い寸の車種別交通量データが必要とな るが，車い寸の車種別に集計した交通量調査はあまり行 われていない，筆者らが平成26年度に，病院付近（信濃 町駅前, 御茶ノ水駅前, 航空公園駅近く）及び首都圈駅 周辺（巣鴨駅, 立川駅, 浦和駅）の横断歩道において歩 行者の観測調查 ${ }^{12)}$ を実施したところ, 手動車いすが171 台，電動車いすは56台（うちハンドル型は1台）であっ た. しかし，この調査にはハンドル型の利用が多いと思 われる郊外の非市街地での調査が含まれていない，その ため，DID地区の交通事故件数と先ほどの車い寸の車種 別交通量でDID地区における事故率を算出してみると, 電動車い寸は484件/56台(=8.6件/台)で, 手動車い寸は290 件/171台 $(=1.7$ 件/台 $)$ となった。この計算には，車い寸の 走行距離の情報等が考慮されていないため完全とは言え ないが，手動車い寸よりも電動車いすの事故のリスクが 高い傾向がうかがえる. このような差異が発生する要因 としては, 電動と手動という性能の差の他に, 手動車い すには介助者がついていることが多いことが挙げられる. 先ほどの観測調查において，手動車い寸には171台中140 台で介助者がついていたのに対し，介助者のいた電動車 い寸は56台中5台のみであった. 介助者がいることで安 全に気を配る人員が増え，自動車等からも見やすくなる ため，事故にあうリスクを抑えることができると考えら れる. 搭乗型移動支援ロボットの実験時にも，このよう な安全保安員を置くことで，事故に巻き込まれるリスク を大きく抑えることができていると思われる.

一方で，電動車い寸と今回想定した搭乗型移動支援口 ボットは, 前述したとおり, 形状や安定性, 操作方法, 
主な利用者層が異なっており，それによる安全対策等の 相違もあると考えられる，片勾配で転倒しや寸い点は， 両者共通しているが，立ち乗り型の搭乗型移動支援ロボ ットは車輪が少なく重心が高いため, 片勾配や路肩での 転倒がより起こりやすくなることが想定される．また， 高さのあるハンドルが転倒時に周囲の歩行者を巻き込む 可能性もある. そのため, 電動車い寸よりも平坦で広幅 員の歩道等での走行が好ましいと推測される. その他に, 立ち乗りであるため, 電動車い寸よりは発見しやすく, 車両等が高速度で衝突してくることが少なくなる点, 利 用者が高齢者ではないため受身等がとれる点，車両等の 速度が速い非市街地での利用が少ないと想定される点等 があり，事故発生時の怪我の程度が軽くなることが考え られる。

\section{6. おわりに}

本研究では, 電動車い寸の交通事故分析から搭乗型移 動支援ロボットの事故の危険性を考察した。その結果, 電動車い寸が交差点以外の車道走行中に重傷以上の事故 に巻き込まれるケースが多いことがわかった. また歩道 があるにもかかわらず電動車い寸が車道を走行して発生 している事故については，歩道の幅員が狭い，段差があ る，歩道が途切れている等のやむをえない事情により車 道を走行している際に事故にあっていると考えられるケ 一スが多くあった。このことから，搭乗型移動支援ロボ ットを安全に用いるためには, 段差や障害物の無いバリ アフリーの歩道を整備していくとともに，やむを得ず車 道を走行するときに備えて, 自動車から発見しやすくす る車体整備が必要であると考えられた，また，搭乗型移 動支援ロボットの利用者に，車両特性と操作技術を身に つけさせるとともに，段差・障害物のある場所や踏切等 では無理に車道を走行せずに，押して歩くことを指導す ることが必要であると考えられる（80kgを超える電動車 い寸と異なり, 本稿で想定した軽量な立ち乗り型の機種 等であれば，押して歩くことも可能）。また，介助者の いることの多い手動車い寸の事故の危険性が低かったこ とから, 搭乗型移動支援ロボットの公道走行実験では安 全保安員をつけることは非常に有効であると考えられた. 今回の研究では，交通事故統計ではカバーできない歩 行者との事故や単独事故については調べきれていない． 搭乗型移動支援ロボットが歩道を走行する場合, 歩行者 との事故を想定した分析をしておくことは必須である.
今後は，交通事故統計にも計上される電動アシスト自転 車と歩行者の事故等の分析を行うことで，歩道内で搭乗 型移動支援ロボットと歩行者が安全に共存する方法を考 えていくことが必要と考えられる. また, 本研究で分析 の対象とした電動車い寸と立ち乗り型の搭乗型移動支援 ロボット等とは相違もあるため, 実証実験や公道外で発 生した事故例を収集し，搭乗型移動支援ロボットの危険 性をより明確に把握していくことが望ましい.

謝辞 : 本研究は科学研究費助成金 (若手(B), 17K18382) の助成を受けて実施したものである.

\section{参考文献}

1) 鶴賀孝廣：モビリティロボットの公道実証実験一特 区制度の利用から全国展開へ一, 日本ロボット学会 誌, Vol. 33, No. 8, pp. 564-567, 2015.

2) 国土交通省：搭乗型移動支援ロボッ卜認定申請の手 引き, 2017.

3）警察庁：「搭乗型移動支援ロボットの公道実証実験」 に係る取扱いについて, 2017.

4) Boniface, K., McKay, M. P., Lucas, R., Shaffer, A. and Sikka, N.: Serious injuries related to the Segway personal transporter: a case series, Annals of Emergency Medicine, Vol. 57, Issue 4, pp. 370-374, 2011.

5)（財）交通事故総合分析センター：電動車い寸の交 通事故, ITARDA INFORMATION, No. 49, 2004.

6) 田平博嗣, 上野義雪 : 歩道単路部の切り下げにおけ る車い寸歩行の負担に時間する実験的検討, 土木計 画学研究・論文集, Vol. 16, pp. 609-616, 1999.

7) 井料美帆, 井料隆雅, 杉森千恵 : パーソナルモビリ ティビークルの交錯回避行動規範の実験的分析, 土 木計画学研究・講演集, No. 52, pp. 1591-1598, 2015.

8) 中川智皓, 今村和樹, 新谷篤彦, 伊藤智博 : パーソ ナルモビリティ・ビークルと歩行者の親和性に関す る実験的研究, 日本機会学会論文集 C 編, Vol. 78, No. 794, pp. 2-12, 2012.

9) 溝端光雄, 北川博巳 : 高齢者のモビリティ確保のた めの電動車い寸利用に関する研究, 土木計画学研 究・講演集, Vol. 26 (CD-ROM), 2002.

10) 経済産業省大臣官房調查統計グループ: 平成 28 年経 済産業省精算動態統計年俸機械統計編, p. 349, 2016.

11）全国軽自動車協会連合会: 平成 28 年 12 月末現在軽四 輪車保有台数と世帯当たり普及台数 $<\mathrm{http}: / /$ www.zenkeijikyo.or.jp/statistics/fukyu-1730>2018 年 3 月 24 日アクセス

12）森健二, 横関俊也, 矢野伸裕, 萩田賢司: 信号付横 断歩道における移動制約者の横断速度, 科学警察研 究所報告, Vol. 66, No. 1, pp. 25-32, 2017.

(Received February 22, 2019) (Accepted August 26, 2019) 


\section{THE RISK OF PMV ASSUMED WITH REFERENCE TO ELECTRIC WHEELCHAIRS TRAFFIC ACCIDENT}

\section{Toshiya YOKOZEKI}

In recent years, various types of PMVs have been developed and put to practical use, around the world. PMV test operation is conducted in Japan also, but it is not sufficiently verified the risk of accident. Therefore, the safety of PMV was examined by analyzing traffic accident of electric wheelchair which is similar to PMV. As a result of the analysis, it turned out that the electric wheelchair running on the moving lane tends to be seriously injured in a traffic accident. In addition, there were features such as narrow sidewalks, steps and obstacles in the accident site occurring in the moving lane despite the presence of sidewalks. In order to expand the use of PMV in Japan, it seemed necessary to prepare wide and stepped walkway network, advanced PMV operation technique, PMV body modification for moving lane driving. 